\title{
Tourism Impacts on Subsistence Agriculture: A Case Study of the Okavango Delta, Botswana
}

\author{
Philippa Harrison ${ }^{1}$ and Brij Maharaj ${ }^{2}$ \\ ${ }^{1}$ University of KwaZulu-Natal, Durban, KwaZulu-Natal, South Africa \\ ${ }^{2}$ Howard College, University of KwaZulu-Natal, Durban, KwaZulu-Natal, South Africa \\ E-mail: maharajB@ukzn.ac.za
}

KEYWORDS Tourism. Okavango Delta. Enclaves. Subsistence Agriculture

\begin{abstract}
The booming tourism industry in the developing countries has been widely viewed as a source of investment, employment and foreign exchange. There is an assumption that the economic benefits of tourism will trickle down to stimulate other sectors of the economy, including agriculture. The government of Botswana, for example, is grappling with the task of developing a tourism policy that will maximize its goals of rural job creation, revenue generation from foreign exchange, conserve and protect wildlife, and be compatible with the cultural norms of its people. As the rural community in the Okavango Delta shifts its focus from agriculture to tourism, several concerns emerge. A key contention of this paper is that a major challenge facing the Okavango Delta region in the twenty first century is an attempt to support the tourism industry without compromising the traditional livelihoods of its local inhabitants. More specifically, as tourism increases economic growth and employment opportunities, it is becoming difficult for local inhabitants to sustain traditional subsistence agricultural livelihoods. As increasing numbers of rural, communal agricultural people migrate to urban areas, the International Union for the Conservation of Nature warned that the uncontrolled expansion of human activities, predominantly associated with tourism, and the foreign control of resources is resulting in the abandonment of many traditional practices, including agriculture, and threatening the livelihoods of the Okavango Delta's inhabitants. Hence, the Okavango Delta presents a unique opportunity to study the impact of tourism on rural agriculture, to observe the negotiation and competition which occurs between global tourism and local agriculture, and to review the inevitable transformation of local culture, economy and physical landscape.
\end{abstract}

\section{INTRODUCTION}

Tourism expanded on a grand scale in the $1960 \mathrm{~s}$ in western industrialised nations and later in developing countries. The booming tourism industry in the south has been widely viewed as a source of investment, employment and foreign exchange (Telfer and Sharpley 2008; Mowforth and Munt 2009). There is an assumption that the economic benefits of tourism will trickle down to stimulate other sectors of the economy, including agriculture (Torres 2002, 2003). This assumption is based on the understanding that tourist-driven demand for greater variety and higher quality of food will encourage local farmers to both increase and diversify production of agricultural goods (Sims 2009). The Government of Botswana, for example, is grappling with the task of developing a tourism policy that will maximize its goals of rural job creation, revenue generation from foreign exchange, conserve and protect wildlife, and be compatible with the cultural norms of its people. Over the past decade there has been a burgeoning published literature on tourism in the Okavango Delta in Botswana focusing on environmental (Mbaiwa 2003) and socio-economic impacts (Mbaiwa 2004, 2005a,b).
As the rural community in the Okavango Delta shifts its focus from agriculture to tourism, several concerns emerge. A key contention of this paper is that a major challenge facing the Okavango Delta region in the twenty first century is an attempt to support the tourism industry without compromising the traditional livelihoods of its local inhabitants. More specifically, as tourism increases economic growth and employment opportunities, it is becoming more difficult for local inhabitants to sustain independent, traditional subsistence agricultural livelihoods. As increasing numbers of ru$\mathrm{ral}$, communal agricultural people migrate to urban areas, the International Union for the Conservation of Nature (IUCN 2000) warned ominously that the unmanaged and uncontrolled expansion of human activities, predominantly associated with tourism, and the foreign control of resources is resulting in the abandonment of many traditional practices, including agriculture, and threatening the livelihoods of the Okavango Delta's inhabitants. Hence, the Okavango Delta presents a unique opportunity to study the impact of tourism on rural agriculture, to observe the negotiation and competition which occurs between global tourism and local agriculture, and to review the inevitable transformation of local culture, economy and physical landscape. 
The Okavango Delta is located in northwest Botswana in the Ngamiland district. Ngamiland district is geographically the third largest in the country, with a total land area of $1,09,130$ square kilometers. The Okavango Delta fluctuates in size, but tends to occupy approximately 15,000 square kilometers during its peak flow season. The major economic activities in the district include tourism, subsistence agriculture, handcrafts and small to medium scale industries, and Maun is the commercial centre.

This paper draws on fieldwork conducted in the Okavango Delta since 2000, including direct observation, official government documentation obtained from the Central Statistics Office (CSO) in Gaborone, Botswana, The Kalahari Conservation Society (KCS); the Department of Wildlife and National Parks (DWNP); the Ministry of Agriculture in Gaborone, Botswana; Botswana Tourism Master Plans, Reports of the World Travel and Tourism Council, and the United Nations Development Programme (which have included surveys with local inhabitants, tourists, retailers, and accommodation providers). This paper is divided into two main sections. The first section focuses on tourism in the Okavango Delta (enclave tourism, employment and training). The second part analyses the associated impacts on rural livelihoods and subsistence agriculture (migration, socio-economic impacts, cultural changes, landuse changes, agricultural and livestock production).

\section{Tourism in the Okavango Delta}

The Hotel and Tourism Association of Botswana (HATAB), established in 1982, is a non-governmental organisation that was at the forefront of tourism development up to the early 1990s, with a private sector membership of over 80 companies. Government policy during this period time was to spend as little as possible on the tourism industry due to its low returns. Hence, the private sector was responsible for investing in the industry with little support from the government (Borge et al. 1989; Ndubano 2000). The situation changed since 1991, with the government taking a very active role in the development of the tourism industry in Botswana. This was because of the government's intention to diversify the country's diamond-based mono-economy, which accounted for 80 percent of exports and one third of the gross domestic product (Ndubano 2000; United Nations Development Programme 2002: 2). It is evident from the table below that there was a phenomenal increase in international tourist arrivals in Botswana between 1995 (521 021) and 2005 as shown in Table 1.

Table 1: International tourist arrivals in Botswana, 1995, 1999 and 2005

\begin{tabular}{|c|c|c|c|c|c|}
\hline \multirow[t]{3}{*}{ Market $^{a}$} & \multicolumn{2}{|c|}{ Arrivals } & \multirow{3}{*}{2005} & \multicolumn{2}{|c|}{ \% annual growth } \\
\hline & 1995 & 1999 & & 1995 & 1999 \\
\hline & & & & -2005 & -2005 \\
\hline South Africa & 242,600 & 393,528 & 785,197 & 12.5 & 12.2 \\
\hline Zimbabwe & 171,671 & 245,630 & 654,115 & 14.3 & 17.7 \\
\hline Other Africa & 48,300 & 81,152 & 318,973 & 20.8 & 25.6 \\
\hline Total Africa & 462,571 & 720,310 & $1,758,285$ & 14.3 & 16.0 \\
\hline USA & 5,493 & 9,871 & 34,422 & 20.1 & 23.1 \\
\hline Canada & 1,021 & 1,573 & 5,226 & 17.7 & 22.2 \\
\hline Other Americas & 239 & 626 & 1,681 & 21.5 & 17.9 \\
\hline Total Americas & 6,753 & 12,070 & 41,329 & 19.9 & 22.8 \\
\hline Australia & 4,003 & 5,577 & 10,218 & 9.8 & 10.6 \\
\hline Japan & 847 & 1,483 & 7,159 & 23.8 & 30.0 \\
\hline Other Asia Pacific & 2,130 & 2,801 & 10,334 & 17.1 & 24.3 \\
\hline Total Asia Pacific & 6,980 & 9,861 & 27,711 & 14.8 & 18.8 \\
\hline UK & 10,231 & 15,519 & 48,701 & 16.9 & 21.0 \\
\hline Germany & 7,237 & 8,209 & 21,627 & 11.6 & 17.5 \\
\hline Netherlands & 2,010 & 4,460 & 12,240 & 19.8 & 18.3 \\
\hline France & 2,081 & 3,219 & 8,677 & 15.3 & 18.0 \\
\hline Italy & 1,220 & 1,651 & 6,011 & 17.3 & 24.0 \\
\hline Other Europe & 5,873 & 10,966 & 30,383 & 17.9 & 18.5 \\
\hline Total Europe & 28,652 & 44,024 & 127,639 & 16.1 & 19.4 \\
\hline Other & 16,065 & 57,049 & 33,063 & 7.5 & -8.7 \\
\hline Total & 521,021 & 843,314 & $1,988,027$ & 14.3 & 15.4 \\
\hline
\end{tabular}

${ }^{a}$ Arrivals country by residence

Source: Statistics Botswana 2008: 17 
While the largest proportion arrived from South Africa and Zimbabwe, tourists from Europe and North America also increased. The economic impacts are summarised in the Table 2.

Table 2: Botswana tourism industry - Economic impacts (2005)

\begin{tabular}{ll}
\hline Tourism variables & Figures \\
\hline Average length of stay (nights) & $5.5 \%$ \\
International tourist expenditure (Pula) & 2.4 billion \\
Average spend per person per day (Pula) & 274 \\
Rooms night sold & 613,069 \\
Bed nights sold & $1,024,623$ \\
Room occupancy rates & $41.5 \%$ \\
Bed occupancy rate & $36.0 \%$ \\
Average length of stay in accommodation & 2.5 \\
$\quad$ (nights) & 237,258 \\
Visits to national parks & 23.6 \\
Revenue at national parks (Pula) & million \\
& \\
Source: Statistics Botswana, 2008: 29 &
\end{tabular}

The growth of tourism in the Okavango Delta led to several socio-economic benefits. These included employment opportunities for the local population, the generation of foreign exchange, the conservation of the Okavango Delta and its natural resources, and the stimulation of infrastructural developments (Mbiawa 2001).

According to the World Travel and Tourism Council (WTTC) in 2007 there were 23226 travel and tourism industry jobs in Botswana, comprising 4.2 percent of the national workforce. This increased to 58783 travel and economy jobs (10.6 percent of the country's workforce) when "government agency employment and supplier company employment" is included (WTTC 2007: 29). The WTTC (2007: 29) estimated that between 2007 and 2017 the travel and tourism industry would grow by 5 percent annually. The wildlife tourism focus has been in the north, concentrated in the Okavango Delta and Chobe National Park, which "together accounted for 95 percent of all national park entries and 91 percent of all park revenues in 2006" (WTTC 2007: 7).

Table 3 shows the employment profile by sectors. Growth is facilitated by the development of various tourism-related businesses in Maun, therefore creating 'spin-off' benefits and increasing employment opportunities for the local population. These businesses include hotel and restaurants, wholesale and retail trade, transport and communication, and real estate as shown in Table 3.

Tourism in the Okavango Delta has stimulated infrastructural developments in Ngamiland district.
Almost all major road networks throughout Botswana have been tarred, making access to northern Botswana and its neighbouring states of Zimbabwe, Namibia and Zambia easier and quicker. Goods and services are now able to reach the Okavango region much more easily, hence increasing the ability of retail companies to bring imported goods into the Delta region. Furthermore, the expansion of the Maun Airport terminal and runway (completed in 1996) has enabled tourists to fly directly from Johannesburg and Gaborone (Mbiawa 2001).

Table 3: Employment profile by major sectors in Ngamiland District

\begin{tabular}{lrc}
\hline Sector & $\begin{array}{c}\text { Employ- } \\
\text { ment }\end{array}$ & $\begin{array}{l}\text { \% of } \\
\text { grand } \\
\text { total }\end{array}$ \\
\hline Agriculture, hunting and forestry & 3373 & 13.48 \\
Fishing & 135 & 0.54 \\
Mining and quarrying & 61 & 0.24 \\
Hotels and restaurants & 1733 & 6.92 \\
Construction & 2840 & 11.35 \\
Manufacturing & 1878 & 7.5 \\
Electricity, gas and water supply & 130 & 0.52 \\
Wholesale and retail trade & 3441 & 13.75 \\
Financial services & 188 & 0.75 \\
Real estate & 663 & 2.65 \\
Public administration & 4462 & 17.83 \\
Transport and communication & 1895 & 7.57 \\
Education & 1896 & 7.58 \\
Health and social work & 814 & 3.25 \\
Other community, social and & 752 & 3 \\
$\quad$ personal services activities & & \\
Private households and employed & 580 & 2.32 \\
persons & & 0.04 \\
Foreign missions, international & 9 & 0.04 \\
$\quad$ organisations & 177 & 0.71 \\
Unclassified & 25027 & 100 \\
\hline Total &
\end{tabular}

Source: Department of Environmental Affairs, 2008: 44-45

\section{Enclave Tourism}

The expansion of tourism in the Okavango Delta has led to the proliferation of hotels (18), lodges (89), guest houses (32), and safari camps (69) in the region (United Nations 2008: 53). The majority of the accommodation facilities were owned by foreigners, but "spillovers and linkages to other services that are predominantly domesticowned, such as tour operators, should not be underestimated" (United Nations 2008: 53). However, the tourism industry is still largely foreign owned for two possible reasons: 
i) "tourism in Ngamiland was historically largely developed by expatriates and continues to rely on global linkages to secure market share...

ii) it may also reflect the absence of a strong entrepreneurial culture as well as appropriate financial products to help citizens capitalise equity, especially in the high value sector of the industry".

Foreigners tend to receive more income from the ownership of tourism businesses and hold better paying jobs within the industry than their local counterparts. As a result, a large proportion of the income generated from the industry is repatriated out of the country by foreigners, back to their home countries. However, in contrast to this, approximately 90 percent of the foreigners involved in major tourism businesses argue that it is the local people who benefit the most from the industry: "locals benefit directly through employment, and tourism money benefits the government coffers and brings about development in the form of infrastructure to Maun and its people" (Ndubano 2000: 52).

Foreigners involved in the tourism industry argue that the tourism revenues are used by the government and North-West District Council to bring about local development in the form of social infrastructure, which is an indirect benefit to the local population (Mbiawa 1999; Ndubano 2000). This is, to a certain extent true. However, infrastructure development in the Delta as a result of tourism growth has done more to increase migration levels, and hence unemployment figures, in the major towns than provide significant employment opportunities for the local population. In addition, when the benefits of tourism are not directly realised by the local population, as is the case in the Okavango Delta, local communities tend to perceive the industry with increasing negativity (Mbiawa 2001).

The development of enclave tourism in the Okavango Delta can, in part, be attributed to the Government's policy of 'high-cost, low-volume' tourism, which was intended to be a means of raising the required revenue for the industry to sustain itself. In order for the local population to benefit from the tourism industry, a system must be put in place where there is provision for locals to finally assume better paying jobs from foreigners. According to Ndubano (2000), attempts to get Batswana employed in higher paying jobs in the tourism industry are failing. The localisation of "up- per level' jobs, such as managerial posts is not occurring because of a lack of commitment on the part of government to push for this, and resistance by foreigners wishing to secure their jobs.

\section{Employment and Training}

As can be seen from Table 3, approximately 25027 individuals are employed in the Ngamiland District. The total population for Ngamiland District is approximately 121924 , therefore, only 20.5 percent of the total districts' population is formally employed (Department of Environmental Affairs 2008: 61). Even with the mass growth of tourism in the district, the formal sector is not developing adequately to alleviate the high unemployment figures, which imposes three burdens on the region:

i. The local population suffers from a lack of adequate income to meet basic needs.

ii. The high unemployment rate tends to result in a highly unequal distribution of income as a relatively small proportion of the population enjoys the rewards of employment and ownership.

iii. The large number of low-income individuals places strain on the regions resources and economy as government aid and financial assistance policies become necessary.

In the Okavango Delta, most jobs associated with the early stages of tourism development, such as construction, recruit males. However, later stage employment tends to support significant numbers of female jobs (Torres 1996). For example, the Delta now has over 1000 hotel rooms requiring daily maid service. However, the majority of these jobs were menial and low paying. In 2006 females comprised 74 percent of the labour force in the hotel and tourism sector (Central Statistics Office 2008: 4).

Unemployment in the Okavango Delta region is unacceptably high, and is one of the major problems facing the region. Even though Botswana has an official unemployment rate of 17 percent (Africa Economic Outlook 2011: 14), the majority of the rural inhabitants in the Delta are subsistence farmers, which is not considered formal employment. Therefore, the actual unemployment rate in Okavango is much higher. About 40 percent of Ngamiland's employable population is unemployed (Central Statistics Office 2008: 109). Furthermore, "lack of growth and diversification in the agricultural sector may accelerate rural-urban migration and hence exacerbate the level of unemployment and urban poverty" (Seleka 2005: 4). Most rural 
households in the Delta contain only one family member who has formal employment, and who is usually located away in a larger town, such as Maun. The remaining household members tend to rely on subsistence agriculture and supplement their incomes through tourism related activities such as craft production.

In the Okavango Delta region, there are very few opportunities for adult training. The development of skills through tourism has had little impact on alleviating poverty and enabling rural dwellers to secure formal employment. Most local tourist employees only receive 'on-the-job' training, which still renders them unqualified, and hence unable to secure better paying jobs in other sectors of the economy (Ashley 2000; Ndubano 2000). Most rural migrants in the Okavango Delta have no formal training or tertiary qualifications and therefore, regardless of which industry they secure jobs in, they will be unqualified and receive minimal income with little chance of promotion (Ndubano 2000).

The tourism industry and its related services attract rural, subsistence farmers with the possibility of formal employment, yet provides minimal 'improvement of living' opportunities as salaries are too low and most of the employment is unskilled and labour intensive. Hence, promotion to significantly higher positions is almost impossible. It can therefore be concluded that although the tourism employment multiplier in the Okavango Delta may be significant, as approximately half of Ngamiland's economically active population are involved in tourism (Table 3 ), the quality of the employment is generally too low to make any major improvements to the livelihoods of the local population.

It is evident from the discussion in the first section of this paper that tourism does not adequately benefit the local population. This challenges the objective of Botswana's tourism policy to diversify the economy, increase development opportunities and uplift impoverished rural communities (Republic of Botswana 2002).

\section{Rural Livelihoods and Subsistence Agriculture}

The expansion of tourism increased the challenges the inhabitants of the Okavango Delta face to preserve their language, culture and traditional way of life. These challenges have their roots in the Okavango people's integration into national, political, social and economic institutions, hunting restrictions placed upon the Okavango Delta since Botswana's independence, and the subsequent development of mass tourism in the area (Bock and Johnson 2002). In the mid-1960s the first commercial safari camps were developed in the Okavango Delta, along the Boro and Jao rivers. This resulted in the first migratory movements of local inhabitants to the periphery of tourist areas (Hitchcock 1991; Bock 1998).

\section{Migration in the Okavango Delta}

The levels of out-migration in the Ngamiland district from 'rural' agricultural areas to the major towns in the region, has increased drastically since the early 1990s. The population of Maun, widely known as the gateway to the Delta, increased by 38.9 percent from 26768 in 1991 to 43776 in 2001 (when the last national census was undertaken). According to the GeoNames geographical database, in 2010 the population of Maun, Botswana is $49945^{1}$, an increase of 12.4 percent. The tourism industry has contributed to this rural-urban migration.

The growth of tourism in the Okavango Delta, especially Maun, has led to significant infrastructure development and resultant employment opportunities in the tourism industry itself, as well as in the retail, trade, wholesale, transportation, education and construction industries and public administration departments. This infrastructure growth has made the major towns in the Delta 'magnets', drawing rural agricultural dwellers to the 'urban' centres and further decimating the already thinly populated rural-agricultural areas (Ndubano 2000).

One of the most significant impacts of tourism growth and infrastructure development in the Okavango Delta has been an increase in school attendance since the early 1990s. According to the Republic of Botswana Demography Survey (1998), the number of individuals in the Ngamiland district who had never attended school declined from 30 percent in 1991 to 21.1 percent in 1998 (Republic of Botswana Statistical Bulletin 2001).

\section{Socio-economic Impacts of Migration in the OkavangoDelta}

The growth in education levels in the district has also contributed to the increase in rural-urban migration in the Delta. In an attempt to increase education levels throughout the country, the Botswana government has established primary 
schools in most of the villages, and high schools with boarding facilities in all the larger towns in the Delta. As a result most rural high school students travel to the 'urban' towns to attend school and this has major socio-economic consequences.

This alters the population demographics of the rural villages in that most individuals within the age group of 15 to 20 years are absent for significant periods of time, attending school. With the increase in migratory movements from rural villages to the larger towns in the Delta over the past ten years, the number of males between the ages of 20 to 40 years in the rural agricultural areas has decreased. This is due to the earliest immigrants typically being males, seeking employment in the larger towns, while their wives and children remain in the villages which provide social safety nets (Daltabuit and Pi-Sunyer 1990).

This tends to alter the family structure and the gender-based division of labour in that the females are left to perform all the agricultural tasks, including those traditionally undertaken by the males. The absence of any male impacts on the local production patterns as less crops are planted and harvested by the remaining female agricultural workers, and this has reduced the agricultural surplus for sale. There has been an overall decline of 35.6 percent in the volume of crops harvested in the Ngamiland region since 1995 (Republic of Botswana Statistical Bulletin 2001). Consequently, poor women are in the majority in rural areas.

There is an increasing trend amongst high school leavers in the Okavango Delta to stay in 'urban' towns to seek formal employment, rather than returning to their agricultural villages to resume their subsistence livelihoods. Hence, ruralurban migration levels increase, and a subsequent decrease in the practice of traditional agriculture in the Okavango Delta.

Migration to urban centres is viewed as a strategy to escape rural poverty. The rural to urban movement of poor farming populations in search of improved income earning opportunities in the Delta has led to an explosive growth in informal housing settlements in all the major towns. Existing basic services, especially in Maun, are unable to support this rapidly growing informal population, and thousands are therefore forced to live in increasingly polluted and degraded conditions (United Nations Development Programme 2002).

\section{Cultural Changes}

Rural migrants generally undergo cultural changes in dress, consumption patterns and lan- guage, replacing their traditional dialect with Setswana and English, following their arrival in the 'urban' towns. Setswana and English are the accepted 'languages of commerce' in Botswana. Hence, a migrant's ability to speak these languages will increase their chances of securing employment. The process of acculturation, however, is gradual. Most migrants tend to initially maintain ties with their home villages, with many returning regularly to participate in seasonal agricultural activities during their first five to ten years in the larger towns (Torres 1996).

International tourism trends suggest a pattern of decline in the importance of local food supplies as a resort develops (Ryan 1991; Torres 1996). The early 'explorer' tourists are generally more willing to experiment with local foods and dishes than later stage mass tourists intent on both minimising costs and consuming familiar foods. The majority of North American, South African and European tourists (Table 1) who visit the Delta tend to have conservative tastes, demanding foods similar to those found in their home countries and resisting indigenous dishes based on locally grown agricultural products (Belisle 1984; Torres 1996).

This trend is increasingly evident in the Okavango Delta with the rapid growth of South African based franchised fast food outlets such as Steers and Nando's in Maun. Such fast food outlets are very cost sensitive, only purchasing produce from franchise approved sources, and emphasising consistency of ingredients. Most fast food outlets, therefore, find it difficult to consider purchasing supplies from local sources (Momsen 1996; Torres 1996). A move away from the use of locally produced foods in the tourism industry is further reinforced by a gradual but persistent shift in the ownership of foreign tourism assets to foreign owners or franchises.

Tourism has also altered consumption patterns in the Okavango Delta through the 'demonstration effect', which occurs when the demand for food by the local population shifts to reflect that of tourists (Torres 1996). This has occurred to a certain extent throughout the Delta, but more acutely in the larger towns, especially in Maun. It would appear that shortly after their arrival in the towns, the consumption behaviour of rural migrants switch from traditional staples to reflect the tastes of long-term urban dwellers. This impacts on local agriculture in that as more rural migrants move to the larger towns, there is a continuous shift away from the consumption of traditional dishes by the 
local population. The local agricultural industry is thus still reliant on the production of traditional staples and is faced with reduced demand. This increases the dependency on food imports as the demand for foreign goods by the local population grows (Torres 1996).

\section{Changes in Land Use in the Okavango Delta}

A large proportion of the rural poor in Botswana rely directly on "environmental resources - land, water and biodiversity - for their livelihoods" (United Nations Development Programme 2002: 2). Agricultural production (livestock keeping and crop production) is a core activity for virtually all rural households in the Okavango Delta. Most households rely on a range of natural resource uses, agricultural and non-agricultural incomes. Diversified strategies are essential in Botswana due to the semi-arid to arid conditions and the common occurrence of drought (Ashley 2000). The poor are directly dependent on "environmental resources - land, water and biodiversity - for their livelihood" (United Nations Development Programme 2002:2).

The development of mass tourism in the Okavango Delta has led to changes in land use in the area. There are two main types of land tenure in the Ngamiland district. These are communal and state land tenure systems. There is no significant freehold land in the district. The amount of land allocated under the two major tenure systems in the Ngamiland district also changed between 1974 and 1995. The share of total land area that fell under the communal land tenure system dropped from 100 677 square kilometers ( 92.3 percent of total district land area) in 1974 to 99399 square kilometers (91.1 percent) in 1981. There was a further drop to 66532 square kilometers (61 percent of total district land area) by the end of 1995 . State land in the district increased from 8453 square kilometers (7.7 percent of total district land area) in 1974 to 9731 square kilometers ( 8.9 percent) in 1981. There was a further increase to 42598 square kilometers (39 percent of total district land area) by the end of 1995 . Therefore, a total of 31.3 percent of total land area in the Ngamiland district was re-allocated from communal land to state land, predominantly for use as WMAs (Republic of Botswana Environmental Statistics 2000).

In the Ngamiland district, pastoral, arable and residential areas, which fall under communal land makes up 60072 square kilometers or 55 percent of total land area. National parks make up 3900 square kilometers or 3.5 percent, and game reserves make up a further 5560 square kilometers or 5.1 percent of total land area in the district. WMAs make up 32 867 square kilometres or 30.1 percent of total district land area. All three of these land uses fall under state land tenure (Republic of Botswana Environmental Statistics 2000).

All ethnic groups in the Okavango Delta traditionally hunted for meat, commercial gain and social cohesion. Meat constituted an important addition to their diet, especially during years of drought when few or no crops were harvested. The sharing of meat amongst the family and neighbours emphasized social and economic obligations, while wildlife trophies such as hides, horns and tusks provided trade commodities (Campbell 1995).

Tourism in the Delta is also responsible for increasing the exposure of wildlife to agricultural production areas, and hence increasing wildlife damage to crops and village infrastructure. The presence of large numbers of elephants in the Delta causes damage to cattle water points. In the region, elephants, hippopotamus, antelope and baboons eat crops and predators such as lions kill livestock (Ashley 2000).

During the 1970s, hunting restriction policies were implemented throughout the Okavango Delta and inhabitants were required to obtain hunting licenses which specified the number and type of animals an individual was allowed to kill. Hunting licenses for lucrative animals such as lions and elephants were too expensive for the average local inhabitant to purchase. The number of animals that each person was allowed to kill during the hunting season was minimal, and as a result almost all animals were used for consumption, which prevented individuals from raising cash to pay taxes and purchase goods (UBS Students Survey of Okavango Villages 1976).

With the implementation of the hunting restriction policies in the Delta, most local inhabitants became poverty stricken and were forced to adopt alternative livelihoods as a means of cash generation. This greatly increased the migration of the inhabitants as many moved to the larger towns in the area in search of employment. The majority of those individuals who remained in the rural villages were forced to adopt full-time subsistence agricultural lifestyles, as this was the only form of cash generation and 'employment' available to the rural dwellers (UBS Students Survey of Okavango Villages 1976). 
The number of people practicing agriculture within the traditional sector in Ngamiland district has decreased from 10466 agricultural holders in 1996 to 10300 holders in 1998. This 1998 figure is the most recent official published statistic for Ngamiland agricultural region. However, it is unofficially estimated that the number of agricultural holders in the district has decreased by approximately 600 holders since 1998 to 9700 holders by the beginning of 2001. Hence, there has been an approximate decrease of 766 agricultural holders ( 7.3 percent) in Ngamiland district from 1996 to 2001 (Republic of Botswana Agricultural Statistics 1996; Republic of Botswana Agricultural Statistics 1998; Republic of Botswana Statistical Bulletin 2001).

The number of agricultural holders in Ngamiland district is, however, not a true reflection of the extent to which agriculture is practiced. This was because many agricultural holders have land, but do not use it for crop production. The agricultural holdings often tend to stay within a family, but are not cultivated. Subsistence farmers who supplement their incomes from work within the tourism industry are often unable to carry out farming activities due to the demand placed on them by the industry. Tourism is a labour intensive industry. Hence, the amount of time taken up by tourism is significant enough to conflict with agricultural production. Therefore, most subsistence farmers who secure employment in the tourism industry are unable to participate in both sectors effectively, and will tend to abandon agriculture in favour of formal employment opportunities (Ashley 2000).

Most subsistence farmers in the Okavango Delta are searching for formal employment and would give up rural agriculture in exchange for 'urban-based' commercial livelihoods, if presented with the opportunity. Although urban salaries are too low to substantially improve their well being, they still receive more income than that from subsistence agriculture (Ndubano 2000).

\section{Changes in Agricultural Production in the OkavangoDelta}

Subsistence agriculture and livestock production were the dominant economic activities practised in Ngamiland until the growth of the tourism industry, and its related infrastructural developments. The agricultural industry, more specifically the livestock industry is the only viable industry in Botswana which is owned and operated by citizens, and hence there is a need for growth within the sector through efficient production and increased market access (Mannathoko 1997).

In 1991 there was a total of 1804 workers formally employed in the agricultural industry. There was a further 6756 individuals practicing traditional sector subsistence agriculture for personal consumption in the Ngamiland district. It is estimated that these subsistence farmers supported a further 40536 individuals in the form of family and relatives. The total population for the Ngamiland district in 1991 was 94534 people. Therefore, approximately 50 percent of the population of Ngamiland was involved in, or dependent upon, subsistence agricultural production in 1991(Republic of Botswana Statistical Bulletin 2001).

In 2001 there was an estimated total of 9700 individuals practicing subsistence agriculture in Ngamiland, and its' total population was approximately 110489 people. Therefore, only nine percent of the population is directly involved in traditional agriculture. Most farmers also receive additional income from family members who hold formal jobs in the larger towns in the Okavango Delta. Hence, the importance of subsistence agriculture in supporting rural households in the Delta has decreased, as most farmers are now supported by formally employed relatives. This is supported by the fact that the number of crops harvested within the traditional sector decreased by 35.6 percent in the Ngamiland district since 1995, while the number of traditional sector cattle, owned by Ngamiland subsistence farmers, decreased by 8,1 percent since 1995 (Republic of Botswana Agricultural Statistics 1996; Republic of Botswana Statistical Bulletin 2001).

\section{Livestock Production}

Livestock production is a major economic activity in Botswana, particularly in the rural areas, as the cattle industry provides valuable income to a significant number of citizens. It is a major source of income, nutrition, draught power and employment in both the rural and urban areas. During the 1995/96 Botswana Meat Commission (BMC) financial year, livestock producers, who sold directly to the BMC, were paid a total of Pula 126 million, while a further Pula 76 million was paid to livestock industry service providers. The Botswana Government received Pula 10.2 million in taxes from the BMC. The BMC supplies approximately 60 percent of beef consumed in the country, while the livestock industry accounts for approximately five 
percent of Botswana's export earnings, which is enough to cover the import costs of basic cereals. The cattle industry therefore plays a significant role in the country's economy, and with improved management systems, the livestock industry's contribution has the potential to be even more substantial (Mannathoko 1997).

In Botswana, livestock production in the traditional sector is dominated by the communal grazing system, in which livestock are not kept in fenced farms, but left to graze in large communal rangelands. This system tends to cause severe damage to the environment through overgrazing as grasses and other plants are not left to mature due to continuous eating by livestock. In the communal areas, the calving rate is 50 percent, and the mortality rate is 12 percent, compared to 60 percent calving rate and five percent mortality rate in fenced farms (Mannathoko 1997).

Botswana's cattle industry has the potential to greatly contribute to the upliftment of the country's rural, subsistence agricultural communities. However, rural farmers in the Okavango Delta, and elsewhere in Botswana, tend to be reluctant to sell their livestock to the BMC for commercial gain. In the 1980s the Botswana Government introduced drought relief subsidies to local farmers throughout the country, with most rural farmers still relying on them to this day. As a result, most rural farmers in the Okavango Delta do not see the need to sell their livestock, as they receive a reliable source of income for not developing their animal herds commercially. There is also a lack of supportive infrastructure in the rural agricultural areas in the Okavango Delta, such as roads, transportation services, electricity and telecommunications. Hence, most rural farmers in the Delta experience great difficulties in transporting their livestock to the BMC in Maun and Gaborone. Therefore, many rural farmers in the Okavango Delta choose to collect drought relief from the government, and keep their livestock for personal consumption, rather than attempting to sell them commercially, even though they would receive more income from their sale than from drought relief (Mannathoko 1997).

The traditional sector livestock industry in the Okavango Delta can only grow if communal rangelands are protected against overgrazing, and if cattle movements are controlled through the fencing in of farms. The implementation of technologies to increase beef production and quality, such as artificial insemination, embryo transplants, rotational grazing and programmed breeding, can only be adopted in fenced farms. In order to achieve this commercial livestock production, supportive infrastructure needs to be implemented in the Okavango Delta. However, this is unlikely to occur because there is pressure on the government to keep the Okavango Delta's rural areas as underdeveloped and pristine as possible for the tourism industry. As a result, most rural farmers in the Okavango Delta do not consider the possibility of developing their livestock into commercial quality beef herds, as they experience difficulty in marketing their animals. Hence, most subsistence farmers in the Delta would abandon their agricultural lifestyles in exchange for formal employment in the larger towns, if the opportunity arose, than attempt to develop their livestock herds and market them commercially (Mannathoko 1997).

There is also a lack of reliable produce marketing outlets in the Okavango Delta, with the Botswana Agricultural Marketing Board (BAMB) being the major outlet for the area. BAMB prices tend to be low and hence many local farmers are reluctant to produce crops commercially due to the limited income they will receive from their sale. It is generally felt that it is more beneficial to grow produce for personal consumption, and only sell the surplus to secure additional income during wetter years. Due to the lack of rural infrastructure in the Delta, local produce also tends to be erratic with regard to both the quantity produced from season to season, and the quality of the crops. This is due to farmers being reliant upon seasonal climatic conditions and fluctuating water sources. As a result, the tourism industry tends to purchase imported produce because there are very limited crops available from the BAMB, as the locals are reluctant to sell their produce. The produce that is available tends to be unreliable (Republic of Botswana Government White Paper No.12002).

The local farmers also lack the necessary education and technology required to produce the crop types demanded by the tourism industry, as only traditional produce such as maize, millet and sorghum are grown. The tourism industry is therefore forced to purchase imported goods as this is the only available source for this type of produce. Significant linkages have therefore not developed between the tourism industry and the local agricultural sector, even though there is the potential for the development of a successful, locally owned, commercial horticultural and livestock sector in the area (Makhwaje et al. 1995; Republic of Botswana Statistical Bulletin 2001; Republic of Botswana Government White Paper No.1 2002). 


\section{CONCLUSION: SOME FINAL THOUGHTS ON TOURISM IN THE OKAVANGO DELTA}

This paper provided an appraisal on the impact of the international tourism industry in the Okavango Delta on rural subsistence agricultural systems, socio-economic structures and employment opportunities in the area. The impact of the development of the tourism industry in the Okavango Delta has not been uniform and varies widely within, and between, communities. The development of tourism has brought about positive changes to the region in the form of infrastructural development, economic growth and employment opportunities. A significant benefit of tourism development on rural subsistence communities in the Okavango Delta has been the provision of cash to individuals involved in the industry. However, tourism income in the region tends to be too low to significantly improve rural livelihoods. One area of concern is the foreign ownership of tourist operations and repatriation of profits, hence backward linkages and multipliers are weak. Food is imported and there is therefore little promotion of local agricultural development.

Tourism is a relatively new rural activity for local communities, and hence, viewed as being a risky venture. It should therefore be perceived as an additional rural activity, to combine with existing agricultural strategies, not as a substitute. Some of the key ways in which tourism impacts on existing rural subsistence activities in the Okavango Delta includes changing food consumption patterns, reducing access to natural resources, creating conflicting demands on time, and worsening wildlife damage. In the Okavango Delta, the large, exclusive areas that have been set aside for wildlife has led to the loss of grazing land and potential agricultural production areas.

In the Okavango Delta there are several interrelated factors that hinder the development of linkages between the tourism industry, and local agricultural production. Firstly, local farmers in the area have not experienced a shift from traditional, subsistence to standardised, commercial patterns of agricultural production. The various agricultural development programmes pursued by the government have, so far, failed to improve the performance of the sector, and to ensure the sustainable use of the region's natural resources. There is also a lack of infrastructure in the rural agricultural areas to support the growth of commercial agricultural and live stock production.
The use of tourism to enhance the livelihoods of rural subsistence dwellers does not simply mean maximising the number of tourism developments in a region, and hence wage income. A wide range of costs and benefits need to be taken into account, particularly the assessment of tourism's impacts on existing rural activities, such as subsistence agriculture. Tourism and agriculture are two sectors that, if linked together, have the potential to stimulate local agriculture, as well as help improve the distribution of tourism benefits to the local people. The Okavango Delta has the potential to create both a thriving local agricultural sector, as well as international tourism ventures that complement each other, without compromise.

\section{NOTES}

1. ODMP Sustainable Tourism and CBNRMC Component, June 2007, p. 45.

2. http: //population.mongabay.com/population/botswana/933366/maun (Retrieved on 12 May 2011).

\section{REFERENCES}

African Economic Outlook 2011. Botswana. From <www.africaneconomicoutlook.org> (Retrieved on 10 June 2011).

Ashley C 2000. The Impacts of Tourism on Rural Livelihoods: Namibia's Experience. Overseas Development Institute: London.

Belisle FJ 1984. Tourism and food production in the Caribbean. Annals of Tourism Research, 10(4): 497513.

Bock J 1998. Economic development and cultural change among the Okavango Delta Peoples. Botswana Notes and Records, 20: 27-44.

Bock J, Johnson SE 2002. The Sociology of Change: The Okavango Delta Peoples of Botswana. Greenwood Press: New York.

Borge L, Nelson WC, Leitch JA, Leistritz LF 1989. Economic Impact of Wildlife Based Tourism in Northern Botswana. North Dakota State University: Fargo.

Campbell A 1995. Utilisation of Wildlife in Botswana from Earliest Times to AD 1900. Kalahari Conservation Society: Gaborone.

Central Statistics Office 2008. 2005/06 Labour Force Report. Gaborone.

Daltabuit M, Pi-Sunyer O 1990. Tourism development in Quintana Roo, Mexico. Cultural Survival Quarterly, 14(1): 9-13.

Hitchcock RK 1991. Tourism and Sustainable Development among Remote Area Populations in Botswana. Botswana Society: Gaborone.

IUCN 2000. Community Benefits through Community Based Natural Resource Management in Botswana. Community Based Natural Resource Management Occasional Paper No. 2. Gland, Switzerland: IUCN.

Mannathoko MM 1997. Agriculture, Particularly the Livestock Industry as a Form of Sustainable Land Use. Kalahari Conservation Society: Gaborone. 
Mbiawa J 2001. The Benefits and Problems of Tourism in the Okavango Delta. University of Botswana: Gaborone.

Mbaiwa JE 2003. The socio-economic and environmental impacts of tourism development on the Okavango Delta, north western Botswana. Journal of Arid Environments, 54: 447-467.

Mbaiwa JE 2004. The socio-cultural impacts of tourism development in the Okavango Delta, Botswana. Journal of Tourism and Cultural Change, 2(3): 163-184.

Mbaiwa JE 2005a. The problems and prospects of sustainable tourism development in the Okavango Delta. Journal of Sustainable Tourism, 13: 203-227.

Mbaiwa JE 2005b. Enclave tourism and its socio-economic impacts in the Okavango Delta. Tourism Management, 26: 157-172.

Momsen J 1996. Linkages between Tourism and Agriculture in the Caribbean. The Hague: Netherlands.

Mowforth M, Munt I 2009. Tourism and Sustainability Development, Globalization and New Tourism in the Third World. $3^{\text {rd }}$ Edition. London: Routledge.

Ndubano E 2000. The Economic Impact of Tourism on the Local People: The Case of Maun in the Ngamiland Sub-District, Botswana. University of Botswana, Gaborone.

Republic of Botswana Agricultural Statistics 1996. Central Statistics Office: Gaborone.

Republic of Botswana Demography Survey 1998a. Central Statistics Office: Gaborone.

Republic of Botswana Agricultural Statistics 1998b. Central Statistics Office: Gaborone.

Republic of Botswana Environmental Statistics 2000. Central Statistics Office: Gaborone.

Republic of Botswana Statistical Bulletin 2001. Central Statistics Office: Gaborone

Republic of Botswana 2002. Botswana National Ecotourism Strategy - Final Report. March 2002.
Ryan C 1991. Recreational Tourism: A Social Science Perspective. Routledge: London.

Statistics Botswana 2008. Research Department, Gaborone. From <www.bedia.co.bw/uploads/files/Botswana\% 20Statistic\%202008.pdf.> (Retrieved on 20 May 2010)

Seleka T B 2005. Challenges for Agricultural Diversification in Botswana under the Proposed SADC-EU Economic Partnership Agreement (EPA). Botswana Institute for Development Policy Analysis (BIPDA). From <www.bipda.bw> (Retrieved on 11 May 2010).

Sims R 2009. Food, place and authenticity: Local food and the sustainable tourism experience. Journal of Sustainable Tourism, 17: 321-336.

Telfer DJ, Sharpley R 2008. Tourism and Development in the Developing World. London: Routledge.

Torres R 1996. The Linkages between Tourism and Agriculture in Quintana Roo, Mexico. University of California: Davis.

Torres R 2002. Toward a better understanding of tourism and agriculture linkages in the Yucatan: Tourist food consumption and preferences. Tourism Geographies, 4: 282-306.

Torres R 2003. Linkages between tourism and agriculture in Mexico. Annals of Tourism Research, 30: 546566.

University of Botswana Students Surveys of Okavango Villages 1976. Rural Sociology Report. Ministry of Agriculture: Gaborone.

WTTC 2007. Botswana - The Impact of Travel and Tourism on the Jobs and the Economy. Report Commissioned by the Government of Botswana and the Botswana Tourism Board . From <http: //www. wttc. org/bin/pdf/original_pdf_file/finwttc_botswana.pdf > (Retrieved on 10 May 2010). 